\title{
A MULTIFUNCIONALIDADE DOS DIREITOS FUNDAMENTAIS POLÍTICOS NO ORDENAMENTO JURÍDICO BRASILEIRO
}

\author{
THE MULTIFUNCTIONALITY OF FUNDAMENTAL POLITICAL \\ RIGHTS IN BRAZILIAN LEGAL SYSTEM \\ Eneida Desiree Salgado ${ }^{1}$ \\ Bárbara Mendonça Bertotti²
}

\begin{abstract}
Recebido em: 14/03/2018 Aceito em: 16/01/2019

desisalg@gmail.com.br barbarabmmab@gmail.com
\end{abstract}

Resumo: O presente artigo tem por finalidade se debruçar sobre a característica da multifuncionalidade nos direitos fundamentais políticos e investigá-los de modo que, a partir da real compreensão destas pretensões, se possa estabelecer premissas para eventuais reformas. Dito de outra forma, pretende-se verificar a compatibilidade das reformas políticas e dos projetos de reforma com a Constituição e com a teoria dos direitos fundamentais, a partir da análise da multifuncionalidade do direito de votar (capacidade eleitoral ativa ou sufrágio ativo) e do direito de concorrer a cargo eletivo (capacidade eleitoral passiva). A conclusão que se chega é que não há na consciência jurídica a interiorização da fundamentalidade dos direitos políticos e, sobretudo, de sua multifuncionalidade, o que faz com que as reformas, no geral, se deem contrariamente aos princípios constitucionais. A metodologia utilizada é a lógico-dedutiva, a partir de uma pesquisa qualitativa e exploratória de algumas leis e propostas de lei e de emendas à Constituição relativas à reforma política, bem como das demais legislações atinentes ao tema, além de revisão bibliográfica sobre os temas envolvidos.

Palavras-chave: Multifuncionalidade. Direitos políticos. Capacidade eleitoral ativa. Capacidade eleitoral passiva. Reforma política.

\begin{abstract}
This article aims to analyze the characteristic of multifunctionality in fundamental political rights and investigate them to a real understanding of these claims to establish premises for any reforms. By another way, it is intended to check the compatibility of the political reforms and its projects with the Constitution and with the theory of fundamental rights, from the analysis of multifunctionality of the right to vote (active electoral capacity or active suffrage) and the right to run for an elective office (passive electoral capacity). The conclusion is that there isn't legal consciousness of the political rights like fundamental rights and, above all, of your multifunctionality, and because of this the reforms, in general, are contrary to constitutional principles. The methodology used is the logical- deductive one, from a qualitative and exploratory research of some laws, bills and amendments to the Constitution regarding political reform, as well as other legislation related to the theme, plus bibliography review on the topics involved.
\end{abstract}

Keywords: Multifunctionality. Political rights. Active electoral capacity. Passive electoral capacity. Political reform.

\section{INTRODUÇÃO: APROXIMAÇÃO ENTRE DIREITOS POLÍTICOS E MULTIFUNCIONALIDADE}

Os direitos políticos são fundamentais e, portanto, possuem proteção constitucional, que atinge não apenas o direito de sufrágio, mas, de igual forma, o direito político passivo. Nesse aspecto,

\footnotetext{
${ }^{1}$ Universidade Federal do Paraná - UFPR - Curitiba - Paraná - Brasil

2 Pontifícia Universidade Católica do Paraná - PUCPR - Curitiba - Paraná - Brasil
} 
possuem suas condições e restrições fundamentadas na Constituição. Assim, como todos os outros direitos fundamentais, os direitos políticos - em sentido amplo, possuem características especiais:

(i) Exibem simultaneamente uma titularidade individual e transindividual, já que algumas das pretensões que deles derivam se enquadram na primeira hipótese, cujos titulares são indivíduos determinados, e outras na segunda ${ }^{3}$, possuindo como titulares um grupo determinado de pessoas ou uma coletividade indeterminável. Por exemplo, o direito ao voto secreto é uma pretensão individual, ao passo que o direito a garantia de eleições periódicas é uma pretensão que atinge toda a coletividade de votantes. Assim como o direito à elegibilidade é um direito individual daqueles que preenchem os requisitos para tanto, e o direito de antena (acesso ao rádio e à televisão) é direito de todos os candidatos.

(ii) São bidimensionais, na medida em que apresentam uma dimensão objetiva e outra subjetiva. A partir desta o titular do direito é investido de exigibilidade (judicial, administrativa ou legal), formando assim uma relação trilateral entre o titular, o objeto e o destinatário do direito, que é obrigado a garanti-lo. Já a perspectiva objetiva vincula a atuação dos poderes públicos, visto que a eficácia dos direitos fundamentais, ao serem materializados na Constituição, incidem sobre todo o ordenamento jurídico. Sendo assim, estes direitos, além de assumirem garantias a seus titulares, representam um conjunto de valores institucionalizados.

(iii) São multifuncionais, na medida em que o direito político em sentido amplo irradia feixes de posições jusfundamentais originando funções ligadas ao respeito, à proteção e à promoção do bem jurídico protegido. Tais funções podem ser sistematizadas em dois grupos: (i) direitos fundamentais como direitos de defesa; e (ii) direitos fundamentais como direitos a prestações. Este último, por sua vez, subdivide-se em dois subgrupos (ii.1) direitos a prestações em sentido amplo (que engloba os direitos de proteção e os direitos à participação na organização e procedimento); e (ii.2) direitos a prestações em sentido estrito (direitos a prestações materiais sociais). ${ }^{4}$

É sobre a multifuncionalidade dos direitos políticos que recai o presente estudo. Muito se tem escrito sobre esta característica dos direitos fundamentais. É possível encontrar textos sobre a multifuncionalidade relativos a diversos direitos fundamentais, como por exemplo: sociais ${ }^{5}$, identidade

\footnotetext{
${ }^{3}$ HACHEM, Daniel Wunder. Tutela administrativa efetiva dos direitos fundamentais sociais: por uma implementação espontânea, integral e igualitária. 614f. Tese (Doutorado em Direito do Estado) - Setor de Ciências Jurídicas, Universidade Federal do Paraná, Curitiba, 2014. p. 175.

${ }^{4}$ SARLET, Ingo Wolfgang. A eficácia dos direitos fundamentais: uma teoria geral dos direitos fundamentais na perspectiva constitucional. 12. ed. rev. atual. e ampl. Porto Alegre: Livraria do Advogado, 2015. p. 173-174. Clèmerson Merlin Clève acrescenta, ainda, uma terceira função aos direitos fundamentais: (iii) a da não discriminação. CLĖVE, Clèmerson Merlin. A eficácia dos direitos fundamentais sociais. Revista de Direito Constitucional e Internacional, [S. I], v. 54, p. 28-39, 2006.
}

5 HACHEM, Daniel Wunder. A dupla titularidade (individual e transindividual) dos direitos fundamentais econômicos, sociais, culturais e ambientais. Revista Direitos Fundamentais \& Democracia (UniBrasil), v. 14, n. 14.1, Curitiba, UniBrasil, p. 618-688, ago./dez. 2013. p. 619-656. Sobre o direito social à previdência: FURIAN, Leonardo. O caráter contributivo da previdência social 
genética $^{6}$, propriedade ${ }^{7}$, liberdade de expressão ${ }^{8}$ e tutela jurisdicional ${ }^{9}$. Contudo, a aproximação dos direitos políticos com o tema ainda é pouco explorada. ${ }^{10}$

Diante de um cenário de desassossego, com inúmeras e infindáveis reformas no cenário eleitoral, ${ }^{11}$ com uma Justiça Eleitoral protagonista, substituindo o Legislativo, e algumas vezes até o eleitor, ofendendo o valor do voto, ${ }^{12} \mathrm{com}$ um Tribunal Superior Eleitoral soberbo, cujas resoluções destroem, constroem e reconstroem o Direito Eleitoral, ${ }^{13}$ e com a sobreposição do Direito pela moral, ${ }^{14}$ se mostra imprescindível investigar com mais cautela os direitos políticos e investigar as inúmeras funções que eles podem exercer.

como um dever fundamental. Fórum Administrativo: Direito Público, Belo Horizonte, v. 11, n. 120, p. 64-79, fev. 2011. Sobre o direito social à saúde: FARIA, Luzardo. Direito Fundamental à Saúde: Regime Jurídico Constitucional e Exigibilidade Judicial. Revista Thesis Juris, São Paulo, v.3, n.2, p. 307-337, jul./dez. 2014.

6 PETTERLE, Selma Rodrigues. 0 direito fundamental à identidade genética na constituição brasileira. 220f. Dissertação (Mestrado em Direito) - Programa de Pós-Graduação da Faculdade de Direito da Pontifícia Universidade Católica do Rio Grande do Sul, Porto Alegre, 2006. f. 119-151.

7 SARLET, Ingo. O Estado Social de Direito, a proibição de retrocesso e a garantia fundamental da propriedade. Revista da Faculdade de Direito da UFRGS, v. 17, p. 111-132, 1999.

8 TAVEIRA, Christiano de Oliveira. Democracia e Pluralismo na Esfera Comunicativa: Uma Proposta de Reformulação do Papel do Estado na Garantia da Liberdade de Expressão. 266f. Tese (Doutorado em Direito Público) - Faculdade de Direito, Universidade do Estado do Rio de Janeiro, Rio de Janeiro, 2010. f. 15-19.

${ }^{9}$ MARINONI, Luiz Guilherme. $O$ direito à tutela jurisdicional efetiva na perspectiva da teoria dos direitos fundamentais. Disponível $\quad$ em: http://www.egov.ufsc.br/portal/sites/default/files/anexos/15441-15442-1-PB.pdf>. Acesso em: 11 fev. 2018.

10 A primeira aproximação com o tema foi realizada no seguinte artigo: SALGADO, Eneida Desiree; BERTOTTI, Bárbara Mendonça. Os direitos políticos no ordenamento brasileiro e a multiplicidade de posições jusfundamentais. In: PINTO, Amanda Luiza Oliveira; BERTOTTI, Bárbara Mendonça; FERRAZ, Miriam Olivia Knopik (orgs.). Reformas Legislativas de um Estado em Crise. Curitiba: Editora Íthala, 2018. p.xx-p.xx.

${ }^{11}$ Após a promulgação da Lei $n^{\circ}$ 9.504/97(Lei das Eleições), que pretendia superar as "leis do ano" e a sucessão casuística na legislação eleitoral, surgiram outras para alterar o processo eleitoral: as Leis ํo 9.840/99, 10.408/02, 10.740/03, 11.300/06, 12.034/09, 12.875/13, 12.891/13, 12.976/14, $13.165 / 15,13.487 / 17$ e 13.488/17. Após as eleições de 2018, novas reformas serão propostas, em uma incessante inovação das regras.

12 Sobre o tema, conferir: COELHO, Margarete de Castro. Sobre o envolvimento de instituições judiciais em disputas políticas: o papel da Justiça Eleitoral Brasileira. In: SANTANO, Ana Claudia; SALGADO, Eneida Desiree. Direito Eleitoral: debates Ibero-americanos. Curitiba: Íthala, 2014. p. 16. 13 Cita-se como exemplo a resolução do TSE $n^{\circ} 22.610$, que, considerada constitucional pelo Supremo Tribunal Federal, disciplina que a desfiliação partidária gera perda de mandato. Frisa-se que o entendimento das autoras deste artigo é que a desfiliação partidária não gera perda de mandato, em face de decisão constituinte que não inclui essa hipótese no rol do artigo 55. Inclusive, defende-se a inconstitucionalidade do "mandato partidário". BRASIL. Tribunal Superior Eleitoral. Resolução do TSE no 22.610 de 25 de outubro de 2007. Disponível em: <http://www.tse.jus.br/arquivos/tseresolucao-22-610>. Acesso em: 11 fev. 2018.

${ }^{14}$ Sobre o tema, conferir: GABARDO, Emerson. Os perigos do moralismo político e a necessidade de defesa do direito posto na Constituição da República de 1988. A\&C- Revista de Direito Administrativo \& Constitucional, Belo Horizonte, ano 17, n. 70, p. 65-91, out./dez. 2017. 
Assim, o objetivo do estudo é verificar a compatibilidade das reformas e dos projetos de reforma com a Constituição e com a teoria dos direitos fundamentais, a partir da análise da multifuncionalidade do direito de votar (capacidade eleitoral ativa ou sufrágio ativo) e do direito de concorrer a cargo eletivo (capacidade eleitoral passiva). Ressalta-se que há outros direitos políticos fundamentais que, em virtude de não se enquadrarem nestes dois eixos, não serão abordados neste trabalho (por exemplo, a iniciativa popular).

\section{AUTODETERMINAÇÃO E PARTICIPAÇÃO POLÍTICA COMO EXIGÊNCIAS DO PRINCÍPIO DEMOCRÁTICO}

A democracia como um projeto moral de autogoverno coletivo exige que os cidadãos, para além de destinatários, atuem como autores das normas gerais de conduta e das estruturas jurídicopolíticas do Estado. De certo modo, a projeção política da autonomia pública e privada, cujo alicerce são os direitos fundamentais, é representada pela democracia. A regra da maioria somente se justifica quando os membros da coletividade são capacitados como agentes morais emancipados e são tratados com igual respeito e consideração. ${ }^{15}$

A doutrina e a filosofia jurídicas deixam evidente a relação entre democracia e direitos fundamentais. John Rawls define os "elementos essenciais constitucionais", que seriam (i) a competência dos três poderes, Judiciário, Legislativo e Executivo, como princípios fundamentais da estrutura do Estado e do processo político; bem como o alcance da regra da maioria; e (ii) as garantias do Estado de Direito e os direitos e liberdades fundamentais e iguais de cidadania que as maiorias legislativas devem respeitar, como por exemplo o direito ao voto e à participação política, a liberdade de consciências e a liberdade de associação. ${ }^{16}$ Para o autor, estas liberdades viabilizam o desenvolvimento de duas capacidades morais do cidadão: as de ter suas próprias concepções de bem e de justiça. ${ }^{17}$

Por sua vez, Dworkin entende que, em uma verdadeira democracia, os cidadãos devem ser considerados agentes morais autônomos, sendo-Ihes assegurados os direitos fundamentais. Ainda, a democracia impõe o tratamento dos cidadãos com igual respeito e consideração, bem como exige que cada um possua juízos próprios de moralidade pessoal. Contudo, dentro do grupo, embora haja

\footnotetext{
15 BINENBOJM, Gustavo. Direitos Fundamentais e democracia como fundamentos estruturantes do Estado democrático de direito. O neoconstitucionalismo e a constitucionalização do direito administrativo. In: Uma teoria do direito administrativo: direitos fundamentais, democracia e constitucionalização.2. ed. rev. e atual. Rio de Janeiro-São Paulo-Recife: Renovar, 2008. p. 50.

${ }^{16}$ RAWLS, John. O liberalismo político. São Paulo: Ática, 2000 p. 277.

17 Para Hannah Arendt, a liberdade é sinônimo de ação política. É uma atividade exercida pelos homens a partir do convívio entre eles, em sua pluralidade. ARENDT, Hannah. O que é política? Tradução de Reinaldo Guarany. Rio de Janeiro: Bertrand Brasil, 2002. p. 21-134.
} 
consciências individuais de pertencimento, a democracia não implica em ações individuais, mas em uma ação coletiva, a quem são imputadas as decisões. ${ }^{18}$

É preciso entender, como Habermas, os direitos fundamentais como condições necessárias do processo democrático e portando imunes à vontade da maioria legislativa. Desse modo, a atuação da jurisdição é legítima quando protege este conjunto de direitos, os quais possibilitam a autonomia privada e política dos cidadãos. ${ }^{19}$

É nesse contexto de liberdades que se encontra a autodeterminação do indivíduo, como sua "liberdade de ação ou omissão sem qualquer constrangimento do Estado", ${ }^{20}$ de modo que os cidadãos são livres para se autogovernarem na sociedade. ${ }^{21}$ A Constituição de um Estado democrático, com Karl Loewenstein, deve reconhecer expressamente uma esfera de autodeterminação individual, com garantias para sua proteção. ${ }^{22}$

Assim deve ser compreendido o caráter deliberativo da democracia, na medida em que todas as partes interessadas participam das discussões e das decisões, ao (i) expressarem seus interesses voluntariamente e de maneira razoavelmente isonômica, justificando-os com argumentos genuínos; (ii) maximizarem a probabilidade de um resultado correto, por meio de uma dimensão apropriada; (iii) formarem maiorias e minorias a cada matéria discutida, sem que grupos sejam isolados; (iv) assegurarem que os indivíduos não se encontrem sujeitos a emoções extraordinárias. ${ }^{23}$

A democracia, portanto, em um primeiro momento, garante o espaço de autonomia individual ao permitir a expressão e exposição do cidadão no debate político de acordo com suas convicções pessoais. Em um segundo momento, o diálogo permite que os interesses particulares se

${ }^{18}$ DWORKIN, Ronald. Liberalismo, Constitución y Democracia. Tradução: Julio Montero y Alfredo Stolarz. Buenos Aires: La isla de la luna, 2003. Mais precisamente no artigo Igualdad, Democracia y Constitución: nosotros, el pueblo, en los estrados.

19 HABERMAS, Jurgen. Direito e Democracia: entre facticidade e validade. vol. I. Tradução: Flávio Beno Siebeneichler. Rio de Janeiro: Tempo Brasileiro, 1997. p. 165.

20 TORRES, Ricardo Lobo. Os direitos humanos e a tributação. Imunidades e isonomia. Rio de Janeiro: Renovar, 1995. p. 55.

21 Jorge Reis Novais ressalva que as renúncias a direitos fundamentais que reificam a pessoa, deixando-a à mercê de outra ou que afetem alguma dimensão de sua autodeterminação presente ou futura, são ilegítimas. Em outros casos, como nos direitos trabalhistas, a Constituição exige disposição legislativa expressa para proteger o trabalhador de decisões que afetem seu direito a uma existência digna. NOVAIS, Jorge Reis. Direitos fundamentais: trunfos contra a maioria. Coimbra: Coimbra, 2006. p. 266 e 277.

22 LOEWENSTEIN, Karl. Teoría de la Constitución. Tradução: Alfredo Gallego Anabitarte. 2. ed. Barcelona: Ariel, 1976. p. 153-154.

${ }^{23}$ NINO, Carlos Santiago. La constitución de la democracia deliberativa. Barcelona: Gedisa, 1996. p. 180. 
transformem em preferências imparciais, ${ }^{24}$ gerando uma ação coletiva comum, como integrante do ideal republicano. ${ }^{25}$

Para Carlos Nino Santiago a participação direta dos indivíduos na tomada de decisões políticas é obrigatória sempre que possível, para minimizar as distorções da representação e o hiato no processo de deliberação. ${ }^{26}$ No atual contexto, é possível afirmar que os dois componentes principais da democracia contemporânea são os partidos políticos e as eleições periódicas. ${ }^{27}$

A democracia brasileira possui contornos fundados na liberdade, na igualdade, na soberania popular, na cidadania, no pluralismo político e na República. Tais premissas decorrem do preâmbulo $^{28}$ e do artigo $1^{1029}$ da Constituição Federal. Sendo assim, compatibiliza-se com a concepção deliberativa da democracia, onde todas as partes interessadas participam das discussões e decisões, voluntariamente e de maneira razoavelmente igual, até que os interesses individuais, por meio da deliberação coletiva, transformem-se, ao menos no campo normativo, na vontade geral. ${ }^{30}$

A Constituição explicita sua opção democrática e deliberativa ao configurar os direitos políticos e as liberdades políticas, com o sufrágio universal e com os instrumentos de participação direta, prevendo princípios que assegurem a igualdade na disputa eleitoral, a liberdade para a criação

${ }^{24}$ NINO, Carlos Santiago. La constitución de la democracia deliberativa. Barcelona: Gedisa, 1996. p. 202.

25 Para Robert Dahl, apenas um governo democrático pode proporcionar uma oportunidade máxima para os indivíduos exercitarem a liberdade de autodeterminação, ou seja, viverem sob leis de sua própria escolha. DAHL, Robert A. Sobre a Democracia. Tradução de Beatriz Sidou. Brasília: Editora Universidade de Brasília, 2001. p. 73.

${ }^{26}$ NINO, Carlos Santiago. La constitución de la democracia deliberativa. Barcelona: Gedisa, 1996. p. 204-205.

${ }^{27}$ ABAL MEDINA, Juan. La muerte y la resurrección de la representación política. Buenos Aires: Fondo de Cultura Económica, 2004. p. 14.

28 "Nós, representantes do povo brasileiro, reunidos em Assembléia Nacional Constituinte para instituir um Estado Democrático, destinado a assegurar o exercício dos direitos sociais e individuais, a liberdade, a segurança, o bem-estar, o desenvolvimento, a igualdade e a justiça como valores supremos de uma sociedade fraterna, pluralista e sem preconceitos, fundada na harmonia social e comprometida, na ordem interna e internacional, com a solução pacífica das controvérsias, promulgamos, sob a proteção de Deus, a seguinte CONSTITUIÇÃO DA REPÚBLICA FEDERATIVA DO BRASIL".

29 "Artigo 10: A República Federativa do Brasil, formada pela união indissolúvel dos Estados e Municípios e do Distrito Federal, constitui-se em Estado Democrático de Direito e tem como fundamentos: I - a soberania; II - a cidadania; III - a dignidade da pessoa humana; IV - os valores sociais do trabalho e da livre iniciativa; $V$ - o pluralismo político. Parágrafo único. Todo o poder emana do povo, que o exerce por meio de representantes eleitos ou diretamente, nos termos desta Constituição".

${ }^{30}$ NINO, Carlos Santiago. La constitución de la democracia deliberativa. Barcelona: Gedisa, 1996. p. 180. 
de partidos políticos e a garantia do acesso direito de antena e ao fundo partidário, o sistema eleitoral proporcional e a divisão federativa das atribuições. ${ }^{31}$

A partir da premissa da autodeterminação e da participação política como exigências do princípio democrático, ${ }^{32}$ bem como da fundamentalidade dos direitos políticos no texto constitucional brasileiro, pretende-se realizar uma abordagem relativa às inúmeras funções que estes direitos assumem no ordenamento.

\section{SUFRÁGIO ATIVO EM SUAS MÚLTIPLAS FUNÇÕES}

A Constituição Federal, em seu artigo 1ำ, parágrafo único, aponta o povo como sendo a origem e a fonte do poder, que o exerce por meio de representantes eleitos ou diretamente. Deste modo é consagrado o princípio da soberania popular, que é viabilizado por meio do voto.

No ordenamento jurídico brasileiro o direito de votar, em seu sentido amplo, compõe-se de vários outros direitos, conhecidos por direitos em sentido estrito.

Sem a pretensão de esgotar a temática, que iria requerer obra de fôlego, serão arroladas algumas pretensões do direito de votar em sentido amplo: (i) direito ao voto livre; (ii) direito à liberdade de opinião; (iii) direito ao sigilo do voto; (iv) direito ao voto direto; (v) direito ao voto pessoal; (vi) direito ao voto com peso igual; (vii) direito à periodicidade do voto; (viii) participação em consultas populares; (ix) accountabillity; (x) representação; (xi) em todos estes direitos em sentido estrito, deve haver a regulamentação e a criação de órgãos e pessoas jurídicas que assegurem seu exercício. A figura 1 ilustra esse cenário.

Figura 1- Multifuncionalidade do direito de votar

31 SALGADO, Eneida Desiree. Princípios constitucionais estruturantes do direito eleitoral. Curitiba, 2010. 354 f. Tese (Doutorado) - Programa de Pós-Graduação em Direito, Universidade Federal do Paraná. Disponível em: http://acervodigital.ufpr.br/bitstream/handle/1884/22321/Tese_Eneida_Desiree_Salgado.pdf?sequenc e=1 >. Acesso em: 13 dez. 2017. f. 21- 22.

32 Sobre participação e teorias da democracia, conferir: PATEMAN, Carole. Participação e Teoria

Democrática. Trad. Luiz Paulo Rouanet. Rio de Janeiro: Paz e Terra, 1992. 


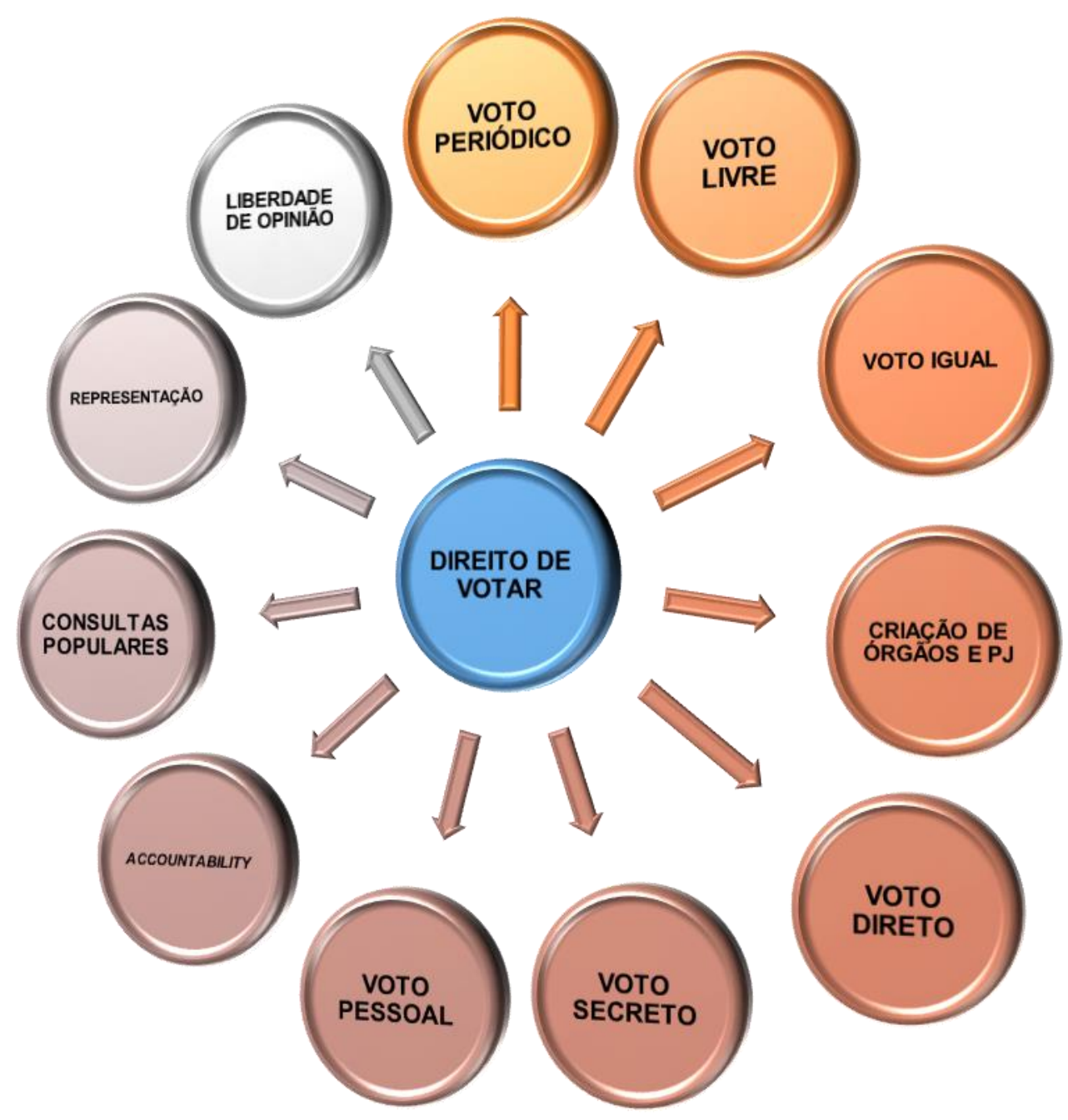

FONTE: Elaborado pelas autoras, 2018.

Estes direitos, ou pretensões jurídicas, possuem funções distintas, gerando para ○ Estado deveres ligados ao respeito, à proteção e à promoção do bem jurídico protegido.

Cabe frisar que, para além do Estado, os direitos fundamentais geram um correspondente dever de respeito e alguns, até mesmo de proteção e promoção, também para os particulares em geral, igualmente vinculados na condição de destinatários das normas de direitos fundamentais. É a chamada "eficácia horizontal" dos direitos fundamentais. ${ }^{33}$

${ }^{33}$ Esta eficácia horizontal já é reconhecida pelo Supremo Tribunal Federal: "As violações a direitos fundamentais não ocorrem somente no âmbito das relações entre o cidadão e o Estado, mas igualmente nas relações travadas entre pessoas físicas e jurídicas de direito privado. Assim, os direitos fundamentais assegurados pela Constituição vinculam diretamente não apenas os poderes públicos, estando direcionados também à proteção dos particulares em face dos poderes privados". BRASIL. STF. Recurso Extraordinário no 201.819-8/RJ. Relator Ministro Gilmar Mendes, segunda turma, $\quad$ D.J. 27.10.2006. Disponível em: http://redir.stf.jus.br/paginadorpub/paginador.jsp?docTP=AC\&docID=388784>. Acesso em: 16 fev. 2018. 
(i) A liberdade do voto manifesta-se pela preferência a um determinado partido político e a certos candidatos, ou também pela faculdade de votar em branco e até mesmo de anular o voto. É uma escolha do eleitor, e o Estado, assim como os particulares, devem se abster de interferir nesta escolha. Assim, o direito ao voto livre possui uma função de defesa, ligada ao dever de respeito.

(ii) Entrelaçada à liberdade do voto está a liberdade de formação de opinião política. Esta se forma coletivamente, "a partir do debate de ideias e da submissão da opinião pessoal à apreciação dos demais. Essa liberdade não prescinde da garantia de uma igualdade entre os candidatos na disputa eleitoral. A existência de vantagens indevidas, baseadas em critérios tidos como irrelevantes, leva ao desvirtuamento do pleito". ${ }^{34}$ Como desdobramento da liberdade formação de opinião, é possível defender que o acesso ao direito de antena deve ser o mais amplo e igualitário possível, assim como a garantia de igualdade na propaganda eleitoral. ${ }^{35}$ Aqui, o Estado deve não somente se abster, mas assegurar que a opinião do eleitor seja formada livre de interferências.

(iii) O sigilo do voto garante a probidade e a lisura no processo eleitoral, pois evita o suborno, a corrupção do voto e a intimidação do eleitor. O Código Eleitoral exige cabine indevassável para garantir o sigilo do voto, pois seu conteúdo não pode ser revelado pelos órgãos da Justiça Eleitoral. ${ }^{36}$ O eleitor é dono de seu segredo após a emissão do voto e a retirada do recinto de votação. Mas no momento de votação, há que preservar o sigilo de seu voto. ${ }^{37}$

A votação eletrônica foi introduzida parcialmente nas eleições de 1996, a fim de dar economicidade e celeridade ao processo eleitoral. Contudo, alvo de inúmeras críticas, este sistema vem sendo questionado, havendo inclusive estudos que demonstraram que o software da urna eletrônica apresenta fragilidades e vulnerabilidades, de modo que o sigilo do voto pode ser completamente violado. ${ }^{38}$

A partir das dúvidas e inquietações acerca da segurança e confiabilidade das urnas eletrônicas, a Lei № 13.165 de 29 de setembro de 2015 veio tornar obrigatória a impressão do voto a partir das eleições gerais de 2018. A votação continuará a ser eletrônica, mas será impresso um

${ }^{34}$ SALGADO, Eneida Desiree. Princípios constitucionais eleitorais. Belo Horizonte: Fórum, 2010. p. 44-45.

${ }^{35}$ SALGADO, Eneida Desiree. Princípios constitucionais eleitorais. Belo Horizonte: Fórum, 2010. p. 198.

36 O sigilo trata-se de tema tão importante que o Código Eleitoral, em seu artigo 220, IV, dispõe que "é nula a votação quando preterida formalidade essencial do sigilo dos sufrágios". Tratam do tema também o artigo 103 do Código Eleitoral, artigo 60, parágrafo 4ํ, Il da Constituição Federal e 0 artigo 59 parágrafos 4ํㅜ e 5ํㅜ e artigo 61 da Lei das Eleições.

37 Vale trazer a possibilidade normativa de que pessoa com deficiência vote com acompanhante de sua escolha. Artigo 7ํㅡㄹ II, alínea c da Resolução no 23.381/12. BRASIL. TSE. Resolução no 23.381 de 19 de junho de 2012. Institui o Programa de Acessibilidade da Justiça Eleitoral. Disponível em: < http://www.tse.jus.br/legislacao-tse/res/2012/RES233812012.htm>. Acesso em: 17 fev. 2018.

38 O estudo foi realizado por pesquisadores do Departamento de Ciência da Computação da Universidade de Brasília, a partir da participação na $2^{\underline{a}}$ edição dos Testes Públicos de Segurança do Sistema Eletrônico de Votação organizada pelo Tribunal Superior Eleitoral, onde foi possível detectar vulnerabilidades no software que permitiram recuperar os votos na ordem em que foram computados. Os pesquisadores ainda apresentam cenários onde estas fragilidades viabilizam a fraude eleitoral e apresentam sugestões para que a segurança seja restaurada. ARANHA, Diego F.; KARAM, Marcelo Monte; MIRANDA; André de; SCAREL, Felipe. Vulnerabilidades no software da urna eletrônica brasileira. Disponível em: <https://lasca.ic.unicamp.br/media/publications/relatorio-urna.pdf>. Acesso em: 16 fev. 2018. 
boletim, para conferência do voto pelo votante, e o processo só será finalizado quando o eleitor confirmar a correspondência entre o voto eletrônico e o registro impresso. O registro impresso será depositado em local previamente lacrado, de forma automática e sem contato manual do eleitor, para garantir o total sigilo do voto. ${ }^{39}$ Esta medida custará $R \$ 2,5$ bilhões de reais aos cofres públicos. ${ }^{40}$

(iv) Os eleitores devem escolher os governantes diretamente, sem intermediários neste ato. Assim, o voto direto impõe que o voto do eleitor seja conferido exatamente ao candidato ou ao partido em quem votou, sem qualquer mediação. A única exceção a esta regra é artigo 81, parágrafo $1^{\circ}$ da Constituição Federal, o qual prevê eleição indireta, pelo Congresso Nacional, em caso de vacância dos cargos de Presidente e Vice-Presidente da República nos últimos dois anos do mandato presidencial.

(v) O voto deve se dar pessoalmente, sem possibilidade de outorga por meio de procuração. ${ }^{41}$ Assim, o Estado deve criar mecanismos para facilitar o acesso dos eleitores às suas respectivas seções eleitorais no dia das eleições, tomando uma postura normativa destinada a promover a inclusão eleitoral das pessoas com deficiência. ${ }^{42}$

Pode-se observar o avanço normativo em algumas ações inclusivas, como, por exemplo, a Resolução no 23.381/12 do TSE, que institui o programa de acessibilidade da justiça eleitoral, destinado "à implementação gradual de medidas para a remoção de barreiras físicas, arquitetônicas, de comunicação e de atitudes, a fim de promover o acesso, amplo e irrestrito, com segurança e autonomia de pessoas portadoras de deficiência ou com mobilidade reduzida no processo eleitoral". ${ }^{43}$

\footnotetext{
${ }^{39}$ Artigo 59-A da Lei das Eleições: "No processo de votação eletrônica, a urna imprimirá o registro de cada voto, que será depositado, de forma automática e sem contato manual do eleitor, em local previamente lacrado. Parágrafo único. O processo de votação não será concluído até que o eleitor confirme a correspondência entre o teor de seu voto e o registro impresso e exibido pela urna eletrônica". BRASIL. Lei 9.504 de 30 de setembro de 1997. Estabelece normas para as eleições. Disponível em: <http://www.planalto.gov.br/ccivil_03/leis/L9504.htm>. Acesso em: 16 fev. 2018.

40 MOURA, Rafael Moraes; PIRES, Breno. Impressão de votos vai custar R \$2,5bi, diz TSE. O Estado de S. Paulo. Disponível em: <http://politica.estadao.com.br/noticias/geral,impressao-de-voto-vaicustar-r-2-5-bi-diz-tse,70001900669>. Acesso em: 16 fev. 2018.

${ }^{41}$ A personalidade é essencial para se verificar a autenticidade do voto.

42 Sobre o voto das pessoas com deficiência, conferir: DAMIA, Fábia Lima de Brito; ARAÚJO, Luiz Alberto David. O direito ao voto das pessoas com deficiência. Revista NEJ - Eletrônica, v. 15, n. 3, p. 327-345, set./dez. 2010; DAMIA, Fábia Lima de Brito. Primeiros Impactos da Lei Brasileira de Inclusão no Direito Eleitoral. Disponível em: < http://www.presp.mpf.mp.br/index.php/noticias/1988primeiros-impactos-da-lei-brasileira-de-inclusao-no-direito-eleitoral\#sdfootnote2anc>. Acesso em: 17 fev. 2018.
}

${ }^{43}$ Artigo $2^{\circ}$ da Resolução. BRASIL. TSE. Resolução ํo 23.381 de 19 de junho de 2012. Institui o Programa de Acessibilidade da Justiça Eleitoral. Disponível em: < http://www.tse.jus.br/legislacaotse/res/2012/RES233812012.htm>. Acesso em: 17 fev. 2018. Antes dessa, outras Resoluções trataram do tema: a ํㅡ 21.008/2002 (BRASIL. TSE. Resolução no 21.008, de 5 de março de 2002. Dispõe sobre 0 voto dos eleitores portadores de deficiência. Disponível em: <http://www.tse.jus.br/legislacao/codigo-eleitoral/normas-editadas-pelo-tse/resolucao-nb0-21.008-de5-de-marco-de-2002-brasilia-2013-df>. Acesso em: 17 fev. 2018), a oㅡ 21.819/2004 (BRASIL. TSE. Resolução no 21.819, de 15 de junho de 2004. Eleições 2004. Atos preparatórios. Corregedoria-Geral Eleitoral. Indagação. Artigos 57, parágrafo único, e 45, inciso III e parágrafo único, ambos da Res.TSE no 21.633. Alcance. Eleitor com necessidades especiais. Voto. Exercício. Sigilo. Princípios. Compatibilização. Critérios. Adoção. Disponível em: <http://www.tse.jus.br/legislacaotse/res/2004/RES219192004.htm>. Acesso em: 17 fev. 2018), e a no 21.920/2004 (BRASIL. TSE. Resolução no 21.920, de 19 de setembro de 2004. Dispõe sobre o alistamento eleitoral e o voto dos cidadãos portadores de deficiência, cuja natureza e situação impossibilitem ou tornem extremamente 
(vi) Igualdade significa que os votos de todos os cidadãos têm o mesmo valor no processo político-eleitoral, ou seja, todas as pessoas têm o mesmo valor no processo político-eleitoral: one man, one vote.

Uma vez que o voto de todos deve apresentar o mesmo peso político, questiona-se se o quociente eleitoral no sistema proporcional viola a efetividade do voto. Nessa medida, candidatos com expressiva votação não logram êxito em conseguir um assento no Parlamento, apenas em função de seu partido não ter conseguido a marca do quociente eleitoral.

Por outro lado, candidatos com ínfima aceitação popular são eleitos, por conta da legenda partidária. Sendo assim, há uma aplicação de peso diferente para votos que deveriam estar assentados na premissa constitucional da isonomia. Nas eleições de 2010, por exemplo, a candidata Luciana Genro, do PSOL, obteve 129.501 votos, sendo a nona candidata mais votada. Contudo, foi derrubada pelo coeficiente eleitoral, de modo que 23 candidatos com número de votos inferior foram eleitos se elegeram para a Câmara dos Deputados. ${ }^{44}$

Essa discrepância foi reduzida, ao ser aprovada medida que permite a participação dos Partidos que não atingiram o quociente eleitoral na distribuição das vagas que sobrarem após a aplicação do quociente partidário. ${ }^{45}$

(vii) A periodicidade garante que o direito de voto será exercido de tempos em tempos. O artigo 60, parágrafo $4^{\circ}$, inciso II, da Carta Maior assegura a temporariedade dos mandatos, uma vez que a democracia representativa prevê e exige existência de mandatos com prazo determinado. A ideia é a de renovação dos cargos eletivos, bem como de temporariedade dos mandatos eletivos.

(viii) O plebiscito e o referendo ${ }^{46}$ também são formas de exercer o direito de voto. Enquanto o primeiro é uma consulta prévia aos cidadãos sobre determinada matéria que posteriormente será discutida pelo Congresso Nacional, o segundo trata-se de uma consulta posterior sobre determinado ato governamental para ratificá-lo, para conceder-Ihe eficácia (condição suspensiva), ou ainda para retirar-Ihe eficácia (condição resolutiva).

Ressalta-se ainda que o termo escrutínio, embora muitas vezes utilizado no sentido estrito para designar apenas $o$ ato de contagem de votos, tem conotações mais amplas no processo

\footnotetext{
oneroso 0 exercício de suas obrigações eleitorais. Disponível em: $<$ http://www.tse.jus.br/legislacao/codigo-eleitoral/normas-editadas-pelo-tse/resolucao-nb0-21.920-de19-de-setembro-de-2004-vitoria-2013-es>. Acesso em: 17 fev. 2018.

44 Jornal do Brasil. Luciana Genro: PSOL não teve alianças no RS por falta de parceiros. Disponível em: <http://m.jb.com.br/eleicoes-2010/noticias/2010/10/10/luciana-genro-psol-nao-teve-aliancas-nors-por-falta-de-parceiros/>. Acesso em: 17 fev. 2018.

${ }^{45}$ Artigo 109, parágrafo $2^{0}$ do Código Eleitoral. BRASIL. Lei no 4.737, de 15 de julho de 1965. Institui o Código Eleitoral. Disponível em: < http://www.planalto.gov.br/ccivil_03/leis/L4737.htm>. Acesso em: 17 fev. 2018.

46 O plebiscito e o referendo, juntamente com a inciativa popular, representam as formas de exercício da soberania popular constantes no artigo 14 da CF. A iniciativa popular trata-se de uma iniciativa de lei, onde se dá o início da formulação da norma. No entanto, está condicionada ao cumprimento das condições propostas no artigo 61 , parágrafo $2^{\circ}$ da CF: "A iniciativa popular pode ser exercida pela apresentação à Câmara dos Deputados de projeto de lei subscrito por, no mínimo, um por cento do eleitorado nacional, distribuído pelo menos por cinco Estados, com não menos de três décimos por cento dos eleitores de cada um deles".
} 
eleitoral, significando o modo de exercício do voto, compreendendo todas as operações eleitorais ${ }^{47}$ concretas destinadas a recolher e apurar os sufrágios, desde as operações de votação até as operações de apuração de votos ${ }^{48}$.

(ix) Accountabilty é um termo abrangente, que vai além do dever de transparência e de prestação de contas pelos gestores da coisa pública, englobando também o controle social por meio de mecanismos de participação popular, ${ }^{49}$ tanto em períodos eleitorais como também ao longo do mandato de seus representantes. ${ }^{50}$ Assim, integram a accountability todas as formas de controle formais e informais. ${ }^{51}$

47 Tais operações estão reguladas no Código Eleitoral, artigos 135 a 156 (Da votação) e 158 a 233 (Das apurações).

48 SILVA, José Afonso da. Curso de Direito Constitucional Positivo. São Paulo: Malheiros, 1992. p. 380. A veracidade do escrutínio, juntamente com a "autenticidade" do voto e a fidedignidade da representação política, são subprincípios do princípio constitucional da autenticidade eleitoral, proposto por Eneida Desiree Salgado, que afirma que a certeza da autenticidade do resultado da votação é uma preocupação desde sempre. SALGADO, Eneida Desiree. Princípios constitucionais eleitorais. Belo Horizonte: Fórum, 2010. p. 48.

${ }^{49} \mathrm{~A}$ promoção da participação popular compreende duas categorias básicas, a transparência e a interatividade, mas ambas se relacionam às informações disponibilizadas pelos portais governamentais e à forma como estas informações são disponibilizadas. VAZ, José Carlos. Limites e Possibilidades do Uso de Portais Municipais para Promoção da Cidadania: a construção de um modelo de análise e avaliação. 2003. 387 f. Tese (Doutorado) - Curso de Doutorado em Administração de Empresas, FGV/EAESP, São Paulo, 2003. p. 144. Nesse sentido, Ana Paula de Barcellos defende que "os deveres de publicidade e de prestação de contas a que estão obrigados os agentes públicos exigem: (i) que os meios de publicidade sejam capazes de levar as informações ao conhecimento real da população, o que no caso brasileiro significa que os meios, além da internet, devem incluir a TV aberta e o rádio; (ii) que as informações veiculadas sejam relevantes, o que significa incluir não apenas dados sobre os recursos investidos (inputs), mas também sobre os serviços planejados (outputs) e os resultados pretendidos (outcomes); e (iii) que as informações relevantes sejam veiculadas com uma determinada periodicidade". BARCELLOS, Ana Paula de. Um debate para o neoconstitucionalismo. Papéis do direito constitucional no fomento do controle social democrático: algumas propostas sobre o tema da informação. Disponível em: $<$ http://www.bfbm.com.br/shared/download/artigo-um-debate-para-o-neoconstitucionalismo.pdf>.

Acesso em: 03 nov. 2017.

${ }^{50}$ Para Bobbio, "toda a história do pensamento político pode ser considerada como uma longa, ininterrupta e apaixonada discussão em torno dos vários modos de limitar o poder: entre eles está o método democrático. Um dos argumentos fortes em favor da democracia é que o povo não pode abusar do poder contra si mesmo, ou, dito de outra forma, onde o legislador e o destinatário da lei são a mesma pessoa, o primeiro não pode prevaricar sobre o segundo". BOBBIO, Norberto. Estado, governo, sociedade: para uma teoria geral da política. 13. ed. Rio de Janeiro: Paz e Terra, 2007. p. 147.

51 Para Carla Sena Pontes, "o alcance da accountability plena está relacionado com a mudança de pensamento dos atores envolvidos no cenário político, principalmente da sociedade, que precisa ter mais interesse pela gestão pública e entender a relação da boa administração com qualidade de vida, já que em uma democracia representativa os interesses dos cidadãos é que devem ser respeitados e não os dos governantes, que quase sempre esquecem o motivo pelo qual foram eleitos e não atingem os resultados condinzentes com suas propostas. Em suma, a sociedade deve ser mais cidadã e a democracia, mais deliberativa". Disponível em: <https://www.maxwell.vrac.pucrio.br/13478/13478_4.PDF>. Acesso em: 13 dez. 2017. PONTES, Carla Sena. A atuação da justiça eleitoral na fiscalização das contas dos candidatos e partidos políticos. Rio de Janeiro, 2008. 213f. Dissertação (mestrado)- Programa de Pós-graduação em Direito da Pontifícia Universidade Católica do Rio de Janeiro. Disponível em: <https://www.maxwell.vrac.pucrio.br/13478/13478_4.PDF>. Acesso em: 13 dez. 2017. 
O controle que os poderes estabelecidos (instituições) exercem uns sobre os outros é conhecida por accountability horizontal, e a necessidade que os representantes têm de prestar contas $^{52}$ e submeter-se ao veredicto da população é chamada de accountability vertical. "É algo que depende de mecanismos institucionais, sobretudo da existência de eleições competitivas periódicas, e que é exercido pelo povo".53 Para Guilhermo O'Donnel, a accountability vertical garante a democracia dos países, visto que permitem que os cidadãos exerçam o papel de escolher quem vai governá-los. ${ }^{54}$

(x) A representação, para Hanna Pitkin "é, em grande medida, um fenômeno cultural e político, um fenômeno humano", que adquiriu diferentes utilizações ao longo da história, mas que abrange uma concepção única a complexa que não mudou significativamente desde o século XVII. ${ }^{55}$

Através do instituto da representação, com amparo jurídico e constitucional, o povo, como figura única, é representado pelo governo. Esta autorização dada pelo povo ao governante se dá por meio do mandato. Este, possui seus limites estabelecidos unicamente na Constituição, de modo que entre os eleitores e os representantes não há estabelecimento de cláusulas e instruções, e nem acordo de vontades e deliberações.

Precisamente, "sequer é possivel se falar em 'representação', pois não há uma vontade préformada. Não se 'representa' algo ou alguém definido perante outrem. Há a construção de uma vontade, limitada apenas aos contornos constitucionais". Salienta-se que a representação precisa estar de acordo com o ideal moderno da igualdade e da autodeterminação. ${ }^{56}$

(xi) Em todos estes direitos em sentido estrito, deve haver a regulamentação e a criação de órgãos e pessoas jurídicas que assegurem seu exercício. Pode-se citar como exemplos: a criação dos Tribunais Regionais Eleitorais, com a finalidade de cumprirem o papel de controle e fiscalização de todo o processo eleitoral sob sua jurisdição; a instituição do Código Eleitoral (Lei № 4.737/1965); a criação do Centro Cultural da Justiça Eleitoral, que visa à preservação do patrimônio histórico e cultural da Justiça Eleitoral, e à difusão de bens culturais de interesse da Justiça Eleitoral; a instituição o Teste Público de Segurança - TPS (Resolução no 23.444/2015, do TSE), que autoriza os órgãos públicos, estudiosos e quaisquer interessados a terem acesso aos componentes internos e

52 Para Ana Cristina Aguilar Viana e Emerson Gabardo, o Brasil possui, como melhor mecanismo de combate à corrupção, a elaboração de legislações punitivistas e simbolicamente rígidas, o que reflete uma mentalidade moralista. VIANA. Ana Cristina Aguilar; GABARDO, Emerson. Crítica à primeira proposta do projeto "dez medidas contra a corrupção": a questão do accountability. In: PINTO, Amanda Luiza Oliveira; BERTOTTI, Bárbara Mendonça; FERRAZ, Miriam Olivia Knopik (orgs.). Reformas Legislativas de um Estado em Crise. Curitiba: Editora Íthala, 2018. p.xx-p.xx.

${ }^{53}$ MIGUEL, Luís Felipe. Impasses da accountability: dilemas e alternativas da representação política. Revista de sociologia e política, n. 25, p. 25-38, nov. 2005.

54 O 'DONNELL, Guillermo. Accountability horizontal e novas poliarquias. Lua Nova [online], n. 44, p. 27-54, 1998. Disponível em: <http://www.scielo.br/scielo.php?pid=S010264451998000200003\&script=sci_abstract\&tlng=pt>. Acesso em: 17 fev. 2018.

55 PITKIN, Hanna Fenichel. Representação: palavras, Instituições e ideias. Lua Nova, São Paulo, n. 67, p. 15-47. 2006.

56 SALGADO, Eneida Desiree. Princípios constitucionais estruturantes do direito eleitoral. Curitiba, 2010. 354 f. Tese (Doutorado) - Programa de Pós-Graduação em Direito, Universidade Federal do Paraná. Disponível em: < http://acervodigital.ufpr.br/bitstream/handle/1884/22321/Tese_Eneida_Desiree_Salgado.pdf?sequenc $\mathrm{e}=1$ >. Acesso em: 13 dez. 2017. f. 29. 
externos do sistema eletrônico de votação, com o intuito de fortalecer a confiabilidade, a transparência e a segurança da votação e da apuração.

Todos estes direitos em sentido estrito, que compõem o direito de votar em sentido amplo, possuem funções distintas, as quais geram, para o Estado e em alguns casos também para os particulares, deveres ligados à proteção, promoção e respeito do direito em questão. Este cenário é ilustrado nas figuras 2 e 3 , a seguir.

Figura 2 - Sistematização das funções do direito de votar



FONTE: Elaborado pelas autoras, 2018.

Figura 3 - Direito de votar: funções e deveres

\begin{tabular}{|l|l|l|l|}
\hline Direito em sentido estrito & Função & Dever do Estado & $\begin{array}{l}\text { Dever dos } \\
\text { particulares }\end{array}$ \\
\hline Voto livre & Defesa & Respeito & Respeito \\
\hline opininião & Defesa/proteção & Respeito/ Proteção & Respeito \\
\hline Voto secreto & Proteção & Proteção & Proteção \\
\hline Voto direto & Proteção & Proteção & \\
\hline Voto pessoal & Proteção & Proteção & Proteção \\
\hline Voto igual & Proteção & Proteção & \\
\hline
\end{tabular}




\begin{tabular}{|l|l|l|l|}
\hline Voto periódico & Proteção & Proteção & - \\
\hline $\begin{array}{l}\text { Votar em consultas } \\
\text { populares }\end{array}$ & Proteção & Proteção & Proteção \\
\hline Accountabillity & Proteção & Proteção & Proteção \\
\hline Representação & Proteção & Proteção & \\
\hline $\begin{array}{l}\text { Regulamentação e } \\
\text { criação de órgãos e } \\
\text { pessoas jurídicas }\end{array}$ & Procedimento/ & Proteção & \\
\hline
\end{tabular}

FONTE: Elaborado pelas autoras, 2018.

\section{CAPACIDADE ELEITORAL PASSIVA E SUA MULTIFUNCIONALIDADE}

O direito de concorrer a cargo eletivo em sentido amplo alberga um conjunto de outros direitos fundamentais, como, exemplificativamente: (i) direito à elegibilidade; (ii) rol de inelegibilidades; (iii) direito ao financiamento de campanha; (iv) direito à propaganda eleitoral; (v) direito à livre expressão; (vi) direito à igualdade de acesso aos cargos; (vii) direito à prestação de contas; (viii) direito de resposta; (ix) regulamentação e criação de órgãos e pessoas jurídicas que assegurem o direito a concorrer a cargo eletivo. A figura 4 expõe este panorama.

Figura 4 - Multifuncionalidade do direito de concorrer a cargo eletivo 


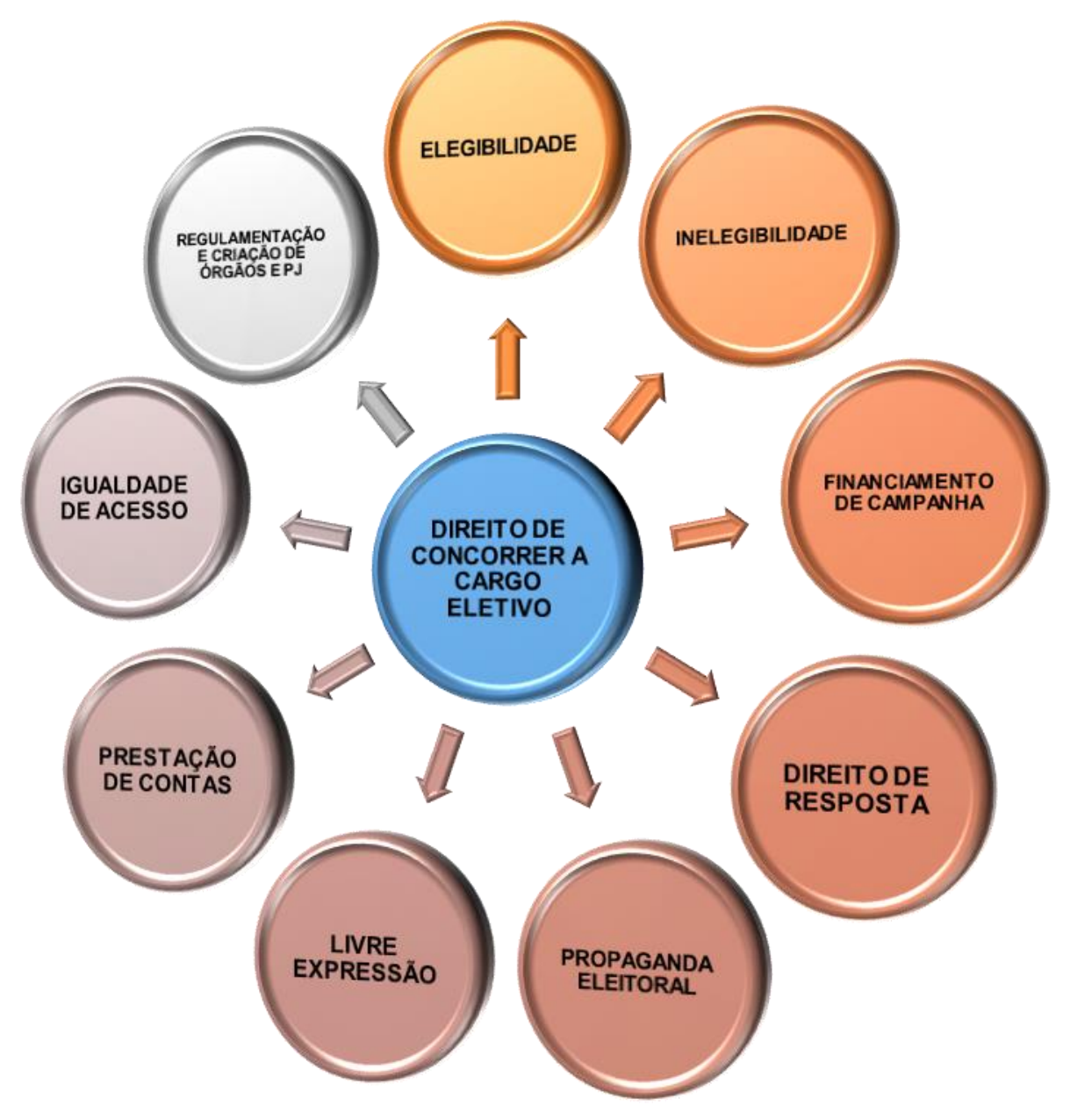

FONTE: Elaborado pelas autoras, 2018.

(i) Elegibilidade refere-se à possibilidade de o indivíduo candidatar-se para ocupar cargos políticos. Para isso, algumas condições previstas na Constituição, chamadas condições de elegibilidade, devem ser atendidas. São elas (artigo 14, parágrafo 3이 da CF): nacionalidade brasileira ou condição de português equiparado, pois apenas estes têm acesso ao alistamento (embora para alguns cargos seja necessária a nacionalidade originária ${ }^{57}$ ); pleno exercício dos direitos políticos; alistamento eleitoral, comprovado pela inscrição eleitoral obtida no juízo eleitoral do domicílio do alistando; domicílio eleitoral na circunscrição ${ }^{58}$; filiação partidária ${ }^{59}$; e idade mínima ${ }^{60}$.

57 O artigo 12, parágrafo $3^{\circ}$ da CF dispõe que são privativos de brasileiro nato os cargos de: Presidente e Vice-Presidente da República; presidente da Câmara dos Deputados; presidente do Senado Federal; Ministro do Supremo Tribunal Federal; carreira diplomática; oficial das forças armadas; Ministro de Estado da Defesa.

58 Conforme o artigo 9ำ da Lei no 9.504/97 (Lei das Eleições), o candidato deve comprovar domicílio eleitoral na respectiva circunscrição pelo prazo de seis meses. O Código Eleitoral, por sua vez, em seu artigo 42, preceitua que "para o efeito da inscrição, é domicílio eleitoral o lugar de residência ou moradia do requerente, e, verificado ter o alistando mais de uma, considerar-se-á domicílio qualquer delas". 
(ii) Porém, para que alguém possa concorrer a um mandato eletivo, além de preencher os requisitos gerais, não deve incidir em alguma das inelegibilidades, que consistem em impedimentos à capacidade eleitoral passiva. As causas de inelegibilidade estão elencadas nos parágrafos $4^{\circ}$ a $7^{\circ}$ do artigo 14 da Constituição Federal61. Por autorização expressa do parágrafo 9ำ do mesmo artigo, esse rol é passível de ampliação por intermédio de lei complementar62.

(iii) Os partidos políticos e os candidatos têm direito a receberem recursos para sua campanha eleitoral. Em que pese os esforços para tornar o sistema de financiamento das campanhas totalmente público, o sistema de financiamento brasileiro é do tipo misto, havendo a proibição de recebimento de recursos financeiros de: entidade ou governo estrangeiros ou de subordinação a estes $^{63}$, doações de pessoas jurídicas ${ }^{64}$; pessoa física que exerça atividade comercial decorrente de concessão ou permissão pública. 65

Desse modo, o financiamento de campanhas e dos partidos políticos pode se dar das seguintes maneiras: (a) Fundo Especial de Financiamento de Campanha (FEFC), criado em 2017, constituído por dotações orçamentárias da União em ano eleitoral, a serem distribuídas aos

\footnotetext{
59 A filiação partidária é regulamentada pela Lei nำ 9.096/95. BRASIL. Lei nำ 9.096, de 19 de setembro de 1995. Dispõe sobre partidos políticos, regulamenta os artigos 17 e 14, parágrafo 3o, inciso V, da Constituição Federal. Disponível em: < http://www.planalto.gov.br/ccivil_03/LEIS/L9096.htm>. Acesso em 18 fev. 2018.

60 Candidatos aos cargos de Presidente e Vice-Presidente da República, e Senador devem contar com 35 anos de idade; aos cargos de Governador e Vice-Governador, 30 anos de idade; aos de Deputado, Prefeito e Vice-Prefeito, 21 anos de idade; ao de Vereador, 18 anos de idade (Artigo 14, parágrafo $3^{\circ}, \mathrm{VI}$, da $\left.\mathrm{CF}\right)$.
}

61 Artigo 14, parágrafo 4ํ- São inelegíveis os inalistáveis e os analfabetos; parágrafo 5 - O Presidente da República, os Governadores de Estado e do Distrito Federal, os Prefeitos e quem os houverem sucedido, ou substituído no curso dos mandatos poderão ser reeleitos para um único período subsequente; parágrafo 6ำ - Para concorrerem a outros cargos, o Presidente da República, os Governadores de Estado e do Distrito Federal e os Prefeitos devem renunciar aos respectivos mandatos até seis meses antes do pleito; parágrafo 7ํㅡ - São inelegíveis, no território de jurisdição do titular, o cônjuge e os parentes consanguíneos ou afins, até o segundo grau ou por adoção, do Presidente da República, de Governador de Estado ou Território, do Distrito Federal, de Prefeito ou de quem os haja substituído dentro dos seis meses anteriores ao pleito, salvo se já titular de mandato eletivo e candidato à reeleição. Os parágrafoparágrafo 6ํㅜ e 7ํㅡㄴ tratam das incompatibilidades.

62 A Lei Complementar nำ64/90, alterada pela Lei Complementar nํ 135/2010, conhecida como a Lei da "Ficha Limpa", veio atender a este dispositivo constitucional. Para aprofundamento no tema, conferir: SALGADO, Eneida Desiree; ARAUJO, Eduardo Borges. Do Legislativo ao Judiciário: a Lei Complementar no 135/2010 (Lei da ficha limpa), a busca pela moralização da vida pública e os direitos fundamentais. A\&C - Revista de Direito Administrativo \& Constitucional (Impresso), v. 54, 2013. p. 121-148; BERTOTTI, Bárbara Marianna de Mendonça A. A Lei Complementar no 135/2010 (Lei da Ficha Limpa), seus aspectos controvertidos e suas repercussões seis anos após sua publicação. Estudos Eleitorais, Brasília, v. 11, n. 3, p. 149-182, set./dez. 2016.

63 Artigo 17, inciso II da Constituição.

64 As doações eleitorais de pessoas jurídicas foram proibidas pelo Supremo Tribunal Federal (STF) em 2015.

$65 \mathrm{O}$ artigo 25 da resolução $\mathrm{n}^{\circ}$ 23.463/15 trata das fontes vedadas. BRASIL. TSE. Resolução $\mathrm{n}^{\circ}$ 23.463, de 15 de dezembro de 2015. Dispõe sobre a arrecadação e os gastos de recursos por partidos políticos e candidatos e sobre a prestação de contas nas eleições de 2016. Disponível em: <http://www.tse.jus.br/legislacao-tse/res/2015/RES234632015.html>. Acesso em: 18 fev. 2018.

Revista do Direito [ISSN 1982-9957]. Santa Cruz do Sul, v. 3, n. 56, p. 81-105, set/dez. 2018. https://online.unisc.br/seer/index.php/direito/index 
partidos $^{66}$; (b) doações de pessoas físicas até o limite de $10 \%$ dos seus rendimentos brutos verificados no ano anterior à eleição;67 (c) financiamento coletivo (crowdfunding);68 (d) venda de bens e serviços pelos partidos; (e) promoção de eventos pelos partidos; (f) autofinanciamento integral da campanha pelo candidato até o limite de gastos para o cargo eletivo. ${ }^{69}$

Concorda-se com Ana Claudia Santano, que "o mais indicado é tornar o processo transparente, é informar o eleitorado quem está financiando as campanhas e os partidos e aperfeiçoar cada vez mais o sistema de fiscalização, sem o ânimo punitivo, mas sim dissuasório". 70

(iv) A propaganda eleitoral no ordenamento brasileiro tem por finalidade (a) difundir os programas partidários; (b) transmitir mensagens aos filiados sobre a execução do programa partidário, dos eventos com este relacionados e das atividades congressuais do partido; (c) divulgar a posição do partido em relação a temas político-comunitários; (d) promover e difundir a participação política feminina, observados os limites legais. ${ }^{71}$

A regulação é feita pela Lei dos Partidos Políticos e pela Lei das Eleições, que asseguram aos partidos, coligações e candidatos acesso gratuito ao rádio e à televisão dentro dos horários disciplinados na Lei, com proibição de propaganda paga, ${ }^{72}$ ressaltando que o objetivo deve ser buscar assegurar a igualdade na disputa.

66 Pela Lei das Eleições (artigo 16-D), a distribuição do FEFC, para o primeiro turno das eleições, ficará assim: $2 \%$ divididos igualmente entre todos os partidos com registro no TSE; $35 \%$ divididos entre as legendas com pelo mesmo um integrante na Câmara dos Deputados, na proporção dos votos conquistados por eles na última eleição geral para a Câmara; $48 \%$ divididos entre os partidos proporcionalmente ao número de deputados na Câmara, consideradas as legendas dos titulares; e $15 \%$ divididos entre os partidos proporcionalmente ao número de senadores, consideradas as legendas dos titulares.

67 Artigo 23, parágrafo $1^{\circ}$ da Lei das Eleições. Para Ana Claudia Santano, "arbitrar limites nominais para as doações privadas também é uma providência muito importante, além de combater as desigualdades na capacidade de financiamento da própria campanha. $O$ desproporcional autofinanciamento percebido nas eleições municipais de 2016 demonstra que o dinheiro sempre encontrará um meio de integrar as arcas partidárias". SANTANO, Ana Cláudia. Parecer jurídico Projeto de Lei 6368/2016, Câmara dos Deputados. Revista Eletrônica Direito e Política, Itajaí, v. 12, n. $1, \quad$ p. $489-508$, jan./abr. $2017 . \quad$ Disponível em: <https://siaiap32.univali.br/seer/index.php/rdp/issue/view/425>. Acesso em: 06 dez. 2017.

68 Para análise desta temática, conferir: SANTANO, Ana Claudia. O financiamento coletivo de campanhas eleitorais como medida econômica de democratização das eleições. Estudos Eleitorais, Brasília, v. 11, n. 2, p. 31-67, maio/ago. 2016.

69 Resolução do TSE no 23.553/2018 (ainda sujeita a alterações).

70 SANTANO, Ana Cláudia. Parecer jurídico - Projeto de Lei 6368/2016, Câmara dos Deputados. Revista Eletrônica Direito e Política, Itajaí, v. 12, n. 1, p. 489-508, jan./abr. 2017. Disponível em: < https://siaiap32.univali.br/seer/index.php/rdp/issue/view/425>. Acesso em: 06 dez. 2017.

71 Sobre a participação da mulher na política, conferir: SANTOS, Polianna Pereira dos; BARCELOS, Júlia Rocha de; PORCARO, Nicole Gondim. Participação da mulher na política: as reformas políticas que temos e as que queremos. In: PINTO, Amanda Luiza Oliveira; BERTOTTI, Bárbara Mendonça; FERRAZ, Miriam Olivia Knopik (orgs.). Reformas Legislativas de um Estado em Crise. Curitiba: Editora Íthala, 2018.

72 Os artigos 36 , parágrafo ${ }^{\circ}$ da Lei das Eleições e o artigo 45, parágrafo6ํ da Lei dos Partidos Políticos vedam a propaganda paga na televisão e no rádio. Para Eneida Desiree Salgado, essa 
(v) A temática da livre expressão do candidato suscita debates, visto que este direito, ao lado do direito à informação da formação de opinião do eleitor, deve se harmonizar com a garantia da lisura do processo eleitoral e da máxima igualdade entre os candidatos.

Desse modo, esse direito fundamental do candidato sofre restrições, e os limites da regulação é questão controversa. Por exemplo, no rádio a na televisão o candidato só pode realizar propaganda eleitoral durante o horário gratuito definido em lei, sendo proibida a veiculação de propaganda paga. ${ }^{73}$

Importante ressaltar que as restrições à liberdade de expressão na propaganda eleitoral não devem se dirigir, indiretamente, à discriminação de grupos sociais ou partidos políticos que não teriam outra forma de se manifestar em virtude dos custos envolvidos. ${ }^{74}$ Ainda, a regulação deve levar em conta que a propaganda está diretamente ligada à formação de opinião do eleitor, de modo que a racionalidade deve imperar, e não a sentimentalidade.

(vi) A igualdade entre os candidatos é corolário do ideal republicano e do princípio democrático, e deve ser assegurada em sua máxima medida.

(vii) Os artigos 28 a 32 da Lei das Eleições disciplinam a prestação de contas, estando os partidos políticos, as coligações e os candidatos obrigados, durante as campanhas eleitorais, a divulgarem em sítio criado pela Justiça Eleitoral para esse fim, na internet, os recursos em dinheiro recebidos para financiamento de sua campanha eleitoral, em até 72 (setenta e duas) horas de seu recebimento; e no dia 15 de setembro do ano eleitoral, relatório discriminando as transferências do Fundo Partidário, os recursos em dinheiro e os estimáveis em dinheiro recebidos, bem como os gastos realizados. ${ }^{75}$

Essa é uma medida que garante a transparência e a legitimidade da atuação partidária no processo eleitoral.

(viii) O direito de resposta é assegurado aos candidatos, partidos ou coligações atingidos, direta ou indiretamente, por conceito, imagem ou afirmação caluniosa, difamatória, injuriosa ou sabidamente inverídica, difundidos por qualquer veículo de comunicação social. ${ }^{76}$

(ix) Regulamentação e criação de órgãos e pessoas jurídicas que assegurem o direito a concorrer a cargo eletivo.

A partir disso, o direito de concorrer a cargo eletivo em sentido amplo alberga um conjunto de direitos que, com suas respectivas funções, geram deveres ao Estado e também aos particulares (figura 5).

Figura 5 - Direito de concorrer a cargo eletivo: funções e deveres

restrição é reflexo do princípio da igualdade entre os candidatos. Observa-se, contudo, certa incoerência do legislador ao permitir a divulgação paga, na imprensa escrita, e a reprodução na Internet do jornal impresso (artigo 43 da Lei das Eleições).

${ }^{73}$ Artigo 44 da Lei das Eleições.

${ }^{74}$ ELY, John Hartigo. Democracy and Distrust: A Theory of Judicial Review. Cambridge: Harvard University Press, 1980. p. 111.

${ }^{75}$ Artigo 28, parágrafo 4ํำ da Lei das Eleições.

${ }^{76}$ Artigo 58 da Lei das Eleições.

Revista do Direito [ISSN 1982-9957]. Santa Cruz do Sul, v. 3, n. 56, p. 81-105, set/dez. 2018. https://online.unisc.br/seer/index.php/direito/index 


\begin{tabular}{|c|c|c|c|}
\hline Direito em sentido estrito & Função & Dever do Estado & $\begin{array}{l}\text { Dever dos } \\
\text { particulares }\end{array}$ \\
\hline Elegibilidade & Proteção & Proteção & - \\
\hline Inelegibilidades & Proteção & Proteção & - \\
\hline $\begin{array}{l}\text { Financiamento de } \\
\text { campanha }\end{array}$ & $\begin{array}{l}\text { Proteção/Prestação } \\
\text { material }\end{array}$ & Proteção/Promoção & Promoção \\
\hline Propaganda eleitoral & Defesa/Proteção & Respeito/Proteção & Respeito \\
\hline Livre expressão & Defesa/ Proteção & Respeito & Respeito \\
\hline $\begin{array}{l}\text { Igualdade de acesso aos } \\
\text { cargos }\end{array}$ & Proteção & Proteção & - \\
\hline Prestação de contas & Proteção & Proteção & - \\
\hline Direito de resposta & Defesa/Proteção & Respeito/Proteção & - \\
\hline $\begin{array}{l}\text { Regulamentação } \\
\text { criação de órgãos e } \\
\text { pessoas jurídicas }\end{array}$ & $\begin{array}{l}\text { Procedimento/ } \\
\text { Organização }\end{array}$ & Proteção & - \\
\hline
\end{tabular}

FONTE: Elaborado pelas autoras, 2018.

\section{5. À GUISA DE CONCLUSÃO: A MULTIFUNCIONALIDADE DOS DIREITOS POLÍTICOS E A REFORMA POLÍTICA}

Em que pese a Constituição estabelecer claramente os direitos políticos entre os direitos fundamentais - e sua relação clara com os princípios republicano e democrático, pilares do Estado de Direito -, não há na consciência jurídica a interiorização desta fundamentalidade. Muito menos, há de se dizer, em relação à sua multifuncionalidade.

Considerar o direito de sufrágio em todo seu potencial implica recusar mudanças constitucionais e legais que restrinjam, por exemplo:

(i) A representatividade, como pode ocorrer caso haja a substituição do princípio proporcional pelo princípio majoritário como chave para a eleição de deputados e vereadores; ao adotar o Distritão, que exclui as minorias da representação, sem falar da (im)possibilidade de renovação na Câmara dos Deputados, reprimindo a alternância necessária em uma verdadeira democracia. Assim, restringir a representação das minorias ofende uma das dimensões do direito de voto e, ao atingir direito fundamental, não se coaduna com os limites de reforma da Constituição.

(ii) A manifestação da vontade do eleitor, de sua liberdade de expressão, como fez o legislador ao proibir a veiculação de material de propaganda eleitoral em bens particulares (artigo 37, 
parágrafo $2^{0}$ da Lei das Eleições) ${ }^{77}$ e ao criminalizar a publicação de novos conteúdos ou o impulsionamento de conteúdos na internet (artigo 39, parágrafo 5ำ, inciso IV da Lei das Eleições). Esta medida se trata de uma ameaça do legislador totalmente contrária ao Estado de Direito, e portanto, inconstitucional.

O mesmo se dá em relação ao direito de concorrer a cargo eletivo. As múltiplas dimensões do direito fundamental estabelecem reservas às mudanças das regras constitucionais e infraconstitucionais, que:

(iii) Desprezem a igualdade de acesso entre os candidatos, como por exemplo o autofinanciamento ilimitado pelo candidato, abrindo espaço para uma "eleição de fidalgos". As regras de financiamento, de igual maneira, devem se voltar a garantir o acesso - de maneira o mais igual possível - dos cidadãos aos cargos eletivos. E assim deve ocorrer com todo o sistema político, partidário e eleitoral.

(iv) Reduzam ou retirem dos candidatos ou partidos a oportunidade de divulgarem seus planos de governo, como fez a Lei $n^{\circ} 13.48 / 17$, ao extinguir a propaganda partidária no rádio e na televisão a partir de $1^{\circ}$ de janeiro de 2018, revogando os artigos $45,46,47,48$, 49 e o parágrafo único do artigo 52 da Lei dos Partidos Políticos, que regulamentavam tal assunto. Ressalta-se que tal medida é contrária ao pluripartidarismo. Ainda, a propaganda eleitoral deve promover uma competição mais igualitária e permitir ao eleitorado o conhecimento das diversas alternativas e das múltiplas propostas em disputa.

(v) Admitam um alargamento das condições de elegibilidade e das hipóteses de inelegibilidade sem fundamentação direta em um bem constitucionalmente protegido. Aliás, muitas das inelegibilidades trazidas pela Lei Complementar no 135/2010 não consideram o caráter de direito fundamental da elegibilidade e não são admissíveis, como, por exemplo, a possibilidade de restringir o direito de concorrer por decisão de órgão de classe.

Tem se observado que a tendência das reformas, no entanto, tem ocorrido em sentido oposto, o que impõe uma alteração das atuais normas. Sem a compreensão dos direitos políticos como direitos fundamentais e de toda a sua multifuncionalidade, não há como se assegurar a existência de uma legítima democracia e de uma autêntica República.

\section{REFERÊNCIAS}

77 Esta vedação foi trazida pela Lei oㅜ 13.488/17, e fez duas ressalvas a esta vedação: bandeiras ao longo de vias públicas, desde que móveis e que não dificultem o bom andamento do trânsito de pessoas e veículos; e adesivo plástico em automóveis, caminhões, bicicletas, motocicletas e janelas residenciais, desde que não exceda a $0,5 \mathrm{~m}^{2}$ (meio metro quadrado). 
ABAL MEDINA, Juan. La muerte y la resurrección de la representación política. Buenos Aires: Fondo de Cultura Económica, 2004.

ARANHA, Diego F.; KARAM, Marcelo Monte; MIRANDA; André de; SCAREL, Felipe. Vulnerabilidades no software da urna eletrônica brasileira. Disponível em:

<https://lasca.ic.unicamp.br/media/publications/relatorio-urna.pdf>. Acesso em: 16 fev. 2018.

ARENDT, Hannah. O que é política? Tradução de Reinaldo Guarany. Rio de Janeiro: Bertrand Brasil, 2002.

BARCELLOS, Ana Paula de. Um debate para o neoconstitucionalismo. Papéis do direito constitucional no fomento do controle social democrático: algumas propostas sobre o tema da informação. Disponível em: <http://www.bfbm.com.br/shared/download/artigo-um-debate-para-oneoconstitucionalismo.pdf>. Acesso em: 03 nov. 2017.

BERTOTTI, Bárbara Marianna de Mendonça A. A Lei Complementar no 135/2010 (Lei da Ficha Limpa), seus aspectos controvertidos e suas repercussões seis anos após sua publicação. Estudos Eleitorais, Brasília, v. 11, n. 3, p. 149-182, set./dez. 2016.

BINENBOJM, Gustavo. Direitos Fundamentais e democracia como fundamentos estruturantes do Estado democrático de direito. O neoconstitucionalismo e a constitucionalização do direito administrativo. In: Uma teoria do direito administrativo: direitos fundamentais, democracia e constitucionalização.2. ed. rev. e atual. Rio de Janeiro-São Paulo-Recife: Renovar, 2008.

BOBBIO, Norberto. Estado, governo, sociedade: para uma teoria geral da política. 13. ed. Rio de Janeiro: Paz e Terra, 2007.

BRASIL. Lei 9.504 de 30 de setembro de 1997. Estabelece normas para as eleições. Disponível em: <http://www.planalto.gov.br/ccivil_03/leis/L9504.htm>. Acesso em: 16 fev. 2018.

BRASIL. Lei no 4.737, de 15 de julho de 1965. Institui o Código Eleitoral. Disponível em: < http://www.planalto.gov.br/ccivil_03/leis/L4737.htm>. Acesso em: 17 fev. 2018.

BRASIL. Lei no 9.096, de 19 de setembro de 1995. Dispõe sobre partidos políticos, regulamenta os artigos 17 e 14, parágrafo $3^{\circ}$, inciso V, da Constituição Federal. Disponível em: < http://www.planalto.gov.br/ccivil_03/LEIS/L9096.htm>. Acesso em 18 fev. 2018.

BRASIL. STF. Recurso Extraordinário oํ 201.819-8/RJ. Relator Ministro Gilmar Mendes, segunda turma, D.J. 27.10.2006. Disponível em: < http://redir.stf.jus.br/paginadorpub/paginador.jsp?docTP=AC\&docID=388784>. Acesso em: 16 fev. 2018.

BRASIL. Tribunal Superior Eleitoral. Resolução do TSE no 22.610 de 25 de outubro de 2007. Disponível em: <http://www.tse.jus.br/arquivos/tse-resolucao-22-610>. Acesso em: 11 fev. 2018.

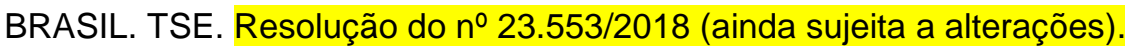

BRASIL. TSE. Resolução no 21.008, de 5 de março de 2002. Dispõe sobre o voto dos eleitores portadores de deficiência. Disponível em: <http://www.tse.jus.br/legislacao/codigo-eleitoral/normaseditadas-pelo-tse/resolucao-nb0-21.008-de-5-de-marco-de-2002-brasilia-2013-df $>$. Acesso em: 17 fev. 2018.

BRASIL. TSE. Resolução oㅜ 21.819, de 15 de junho de 2004. Eleições 2004. Atos preparatórios. Corregedoria-Geral Eleitoral. Indagação. Artigos 57, parágrafo único, e 45, inciso III e parágrafo único, ambos da Res.TSE no 21.633. Alcance. Eleitor com necessidades especiais. Voto. Exercício. Sigilo. Princípios. Compatibilização. Critérios. Adoção. Disponível em: <http://www.tse.jus.br/legislacaotse/res/2004/RES219192004.htm>. Acesso em: 17 fev. 2018. 
BRASIL. TSE. Resolução no 21.920, de 19 de setembro de 2004. Dispõe sobre o alistamento eleitoral e o voto dos cidadãos portadores de deficiência, cuja natureza e situação impossibilitem ou tornem extremamente oneroso o exercício de suas obrigações eleitorais. Disponível em:

$<$ http://www.tse.jus.br/legislacao/codigo-eleitoral/normas-editadas-pelo-tse/resolucao-nb0-21.920-de19-de-setembro-de-2004-vitoria-2013-es>. Acesso em: 17 fev. 2018.

BRASIL. TSE. Resolução no 23.381 de 19 de junho de 2012. Institui o Programa de Acessibilidade da Justiça Eleitoral. Disponível em: < http://www.tse.jus.br/legislacao-tse/res/2012/RES233812012.htm>. Acesso em: 17 fev. 2018.

BRASIL. TSE. Resolução no 23.463, de 15 de dezembro de 2015. Dispõe sobre a arrecadação e os gastos de recursos por partidos políticos e candidatos e sobre a prestação de contas nas eleições de 2016. Disponível em: <http://www.tse.jus.br/legislacao-tse/res/2015/RES234632015.html>. Acesso em: 18 fev. 2018.

CLĖVE, Clèmerson Merlin. A eficácia dos direitos fundamentais sociais. Revista de Direito Constitucional e Internacional, [S. I], v. 54, p. 28-39, 2006.

COELHO, Margarete de Castro. Sobre o envolvimento de instituições judiciais em disputas políticas: o papel da Justiça Eleitoral Brasileira. In: SANTANO, Ana Claudia; SALGADO, Eneida Desiree. Direito Eleitoral: debates Ibero-americanos. Curitiba: Íthala, 2014.

DAHL, Robert A. Sobre a Democracia. Tradução de Beatriz Sidou. Brasília: Editora Universidade de Brasília, 2001.

DAMIA, Fábia Lima de Brito; ARAÚJO, Luiz Alberto David. O direito ao voto das pessoas com deficiência. Revista NEJ - Eletrônica, v. 15, n. 3, p. 327-345, set./dez. 2010; DAMIA, Fábia Lima de Brito. Primeiros Impactos da Lei Brasileira de Inclusão no Direito Eleitoral. Disponível em: < http://www.presp.mpf.mp.br/index.php/noticias/1988-primeiros-impactos-da-lei-brasileira-de-inclusaono-direito-eleitoral\#sdfootnote2anc>. Acesso em: 17 fev. 2018.

DWORKIN, Ronald. Liberalismo, Constitución y Democracia. Tradução: Julio Montero y Alfredo Stolarz. Buenos Aires: La isla de la luna, 2003.

ELY, John Hartigo. Democracy and Distrust: A Theory of Judicial Review. Cambridge: Harvard University Press, 1980.

FARIA, Luzardo. Direito Fundamental à Saúde: Regime Jurídico Constitucional e Exigibilidade Judicial. Revista Thesis Juris, São Paulo, v.3, n.2, p. 307-337, jul./dez. 2014.

FURIAN, Leonardo. O caráter contributivo da previdência social como um dever fundamental. Fórum Administrativo: Direito Público, Belo Horizonte, v. 11, n. 120, p. 64-79, fev. 2011.

GABARDO, Emerson. Os perigos do moralismo político e a necessidade de defesa do direito posto na Constituição da República de 1988. A\&C- Revista de Direito Administrativo \& Constitucional, Belo Horizonte, ano 17, n. 70, p. 65-91, out./dez. 2017.

HABERMAS, Jurgen. Direito e Democracia: entre facticidade e validade. vol. I. Tradução: Flávio Beno Siebeneichler. Rio de Janeiro: Tempo Brasileiro, 1997.

HACHEM, Daniel Wunder. A dupla titularidade (individual e transindividual) dos direitos fundamentais econômicos, sociais, culturais e ambientais. Revista Direitos Fundamentais \& Democracia (UniBrasil), v. 14, n. 14.1, Curitiba, UniBrasil, p. 618-688, ago./dez. 2013.

HACHEM, Daniel Wunder. Tutela administrativa efetiva dos direitos fundamentais sociais: por uma implementação espontânea, integral e igualitária. 614f. Tese (Doutorado em Direito do Estado) - Setor de Ciências Jurídicas, Universidade Federal do Paraná, Curitiba, 2014. 
Jornal do Brasil. Luciana Genro: Psol não teve alianças no RS por falta de parceiros. Disponível em: <http://m.jb.com.br/eleicoes-2010/noticias/2010/10/10/luciana-genro-psol-nao-teve-aliancas-no-rs-porfalta-de-parceiros/>. Acesso em: 17 fev. 2018.

LOEWENSTEIN, Karl. Teoría de la Constitución. Tradução: Alfredo Gallego Anabitarte. 2. ed. Barcelona: Ariel, 1976.

MARINONI, Luiz Guilherme. $O$ direito à tutela jurisdicional efetiva na perspectiva da teoria dos direitos fundamentais. Disponível em: <

http://www.egov.ufsc.br/portal/sites/default/files/anexos/15441-15442-1-PB.pdf>. Acesso em: 11 fev. 2018.

MIGUEL, Luís Felipe. Impasses da accountability: dilemas e alternativas da representação política. Revista de sociologia e política, n. 25, p. 25-38, nov. 2005.

MOURA, Rafael Moraes; PIRES, Breno. Impressão de votos vai custar R\$2,5bi, diz TSE. O Estado de S. Paulo. Disponível em: <http://politica.estadao.com.br/noticias/geral,impressao-de-voto-vaicustar-r-2-5-bi-diz-tse,70001900669>. Acesso em: 16 fev. 2018.

NINO, Carlos Santiago. La constitución de la democracia deliberativa. Barcelona: Gedisa, 1996.

NOVAIS, Jorge Reis. Direitos fundamentais: trunfos contra a maioria. Coimbra: Coimbra, 2006.

O 'DONNELL, Guillermo. Accountability horizontal e novas poliarquias. Lua Nova [online], n. 44, p. 27-54, 1998. Disponível em: <http://www.scielo.br/scielo.php?pid=S0102-

64451998000200003\&script=sci_abstract\&tlng=pt>. Acesso em: 17 fev. 2018.

PATEMAN, Carole. Participação e Teoria Democrática. Trad. Luiz Paulo Rouanet. Rio de Janeiro: Paz e Terra, 1992.

PETTERLE, Selma Rodrigues. 0 direito fundamental à identidade genética na constituição brasileira. 220f. Dissertação (Mestrado em Direito) - Programa de Pós-Graduação da Faculdade de Direito da Pontifícia Universidade Católica do Rio Grande do Sul, Porto Alegre, 2006.

PITKIN, Hanna Fenichel. Representação: palavras, Instituições e ideias. Lua Nova, São Paulo, n. 67, p. 15-47. 2006.

PONTES, Carla Sena. A atuação da justiça eleitoral na fiscalização das contas dos candidatos e partidos políticos. Rio de Janeiro, 2008. 213f. Dissertação (mestrado)- Programa de Pós-graduação em Direito da Pontifícia Universidade Católica do Rio de Janeiro. Disponível em:

<https://www.maxwell.vrac.puc-rio.br/13478/13478_4.PDF>. Acesso em: 13 dez. 2017.

RAWLS, John. O liberalismo político. São Paulo: Ática, 2000.

SALGADO, Eneida Desiree; ARAUJO, Eduardo Borges. Do Legislativo ao Judiciário: a Lei Complementar no 135/2010 (Lei da ficha limpa), a busca pela moralização da vida pública e os direitos fundamentais. A\&C - Revista de Direito Administrativo \& Constitucional (Impresso), v. 54, p. 121-148. 2013.

SALGADO, Eneida Desiree; BERTOTTI, Bárbara Mendonça. Os direitos políticos no ordenamento brasileiro e a multiplicidade de posições jusfundamentais. In: PINTO, Amanda Luiza Oliveira; BERTOTTI, Bárbara Mendonça; FERRAZ, Miriam Olivia Knopik (orgs.). Reformas Legislativas de um Estado em Crise. Curitiba: Editora Íthala, 2018.

SALGADO, Eneida Desiree. Princípios constitucionais eleitorais. Belo Horizonte: Fórum, 2010.

SALGADO, Eneida Desiree. Princípios constitucionais estruturantes do direito eleitoral. Curitiba, 2010. 354 f. Tese (Doutorado) - Programa de Pós-Graduação em Direito, Universidade Federal do Paraná. Disponível em: < 
http://acervodigital.ufpr.br/bitstream/handle/1884/22321/Tese_Eneida_Desiree_Salgado.pdf?sequenc e=1>. Acesso em: 13 dez. 2017.

SANTANO, Ana Claudia. O financiamento coletivo de campanhas eleitorais como medida econômica de democratização das eleições. Estudos Eleitorais, Brasília, v. 11, n. 2, p. 31-67, maio/ago. 2016.

SANTANO, Ana Cláudia. Parecer jurídico - Projeto de Lei 6368/2016, Câmara dos Deputados.

Revista Eletrônica Direito e Política, Itajaí, v. 12, n. 1, p. 489-508, jan./abr. 2017. Disponível em: <https://siaiap32.univali.br/seer/index.php/rdp/issue/view/425>. Acesso em: 06 dez. 2017.

SANTOS, Polianna Pereira dos; BARCELOS, Júlia Rocha de; PORCARO, Nicole Gondim. Participação da mulher na política: as reformas políticas que temos e as que queremos. In: PINTO, Amanda Luiza Oliveira; BERTOTTI, Bárbara Mendonça; FERRAZ, Miriam Olivia Knopik (orgs.). Reformas Legislativas de um Estado em Crise. Curitiba: Editora Íthala, 2018.

SARLET, Ingo Wolfgang. A eficácia dos direitos fundamentais: uma teoria geral dos direitos fundamentais na perspectiva constitucional. 12. ed. rev. atual. e ampl. Porto Alegre: Livraria do Advogado, 2015.

SARLET, Ingo. O Estado Social de Direito, a proibição de retrocesso e a garantia fundamental da propriedade. Revista da Faculdade de Direito da UFRGS, v. 17, p. 111-132, 1999.

SILVA, José Afonso da. Curso de Direito Constitucional Positivo. São Paulo: Malheiros, 1992.

TAVEIRA, Christiano de Oliveira. Democracia e Pluralismo na Esfera Comunicativa: Uma Proposta de Reformulação do Papel do Estado na Garantia da Liberdade de Expressão. 266f. Tese (Doutorado em Direito Público) - Faculdade de Direito, Universidade do Estado do Rio de Janeiro, Rio de Janeiro, 2010.

TORRES, Ricardo Lobo. Os direitos humanos e a tributação. Imunidades e isonomia. Rio de Janeiro: Renovar, 1995.

VAZ, José Carlos. Limites e Possibilidades do Uso de Portais Municipais para Promoção da Cidadania: a construção de um modelo de análise e avaliação. 2003. 387 f. Tese (Doutorado) Curso de Doutorado em Administração de Empresas, FGV/EAESP, São Paulo, 2003.

VIANA. Ana Cristina Aguilar; GABARDO, Emerson. Crítica à primeira proposta do projeto "dez medidas contra a corrupção": a questão do accountability. In: PINTO, Amanda Luiza Oliveira; BERTOTTI, Bárbara Mendonça; FERRAZ, Miriam Olivia Knopik (orgs.). Reformas Legislativas de um Estado em Crise. Curitiba: Editora Íthala, 2018.

\section{COMO CITAR ESSE DOCUMENTO:}

SALGADO, Eneida Desiree; BERTOTTI, Bárbara Mendonça. A multifuncionalidade dos direitos fundamentais políticos no ordenamento jurídico brasileiro. Revista do Direito, Santa Cruz do Sul, v. 3, n. 56, jan. 2019. ISSN 1982-9957. Disponível em: <https://online.unisc.br/seer/index.php/direito/article/view/11810>. Acesso em: doi:https://doi.org/10.17058/rdunisc.v3i56.11810. 